\title{
Solvation Interactions of Tetrapyridylporphyrin Derivatives in Aqueous Solutions
}

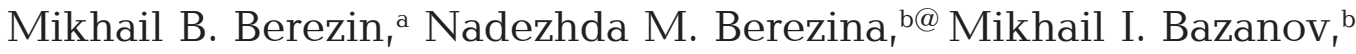 \\ and Alexander S. Semeikin ${ }^{\mathrm{b}}$ \\ anstitute of Solution Chemistry of Russian Academy of Sciences, 153045 Ivanovo, Russia \\ ${ }^{b}$ Ivanovo State University of Chemistry and Technology, 153000 Ivanovo, Russia \\ ${ }^{\circledR}$ Corresponding author E-mail: sky_berezina@rambler.ru
}

\begin{abstract}
Enthalpies of dissolution of tetrapyridylporphyrin (TPyP) derivatives, in which the pyridine nitrogen is located in para-, meta- or ortho-positions and is modified by nonpolar $\left(-\mathrm{CH}_{3},-\mathrm{C}_{2} \mathrm{H}_{5},-\mathrm{C}_{3} \mathrm{H}_{7}\right)$, polar $\left(-\mathrm{CH}_{2} \mathrm{COOH},-\mathrm{CH}_{2} \mathrm{CH}_{2} \mathrm{COOH}\right)$ and low-polar $\left(-\mathrm{CH}_{2} \mathrm{COOC}_{2} \mathrm{H}_{5}\right)$ groups, are determined in water by calorimetric method for the first time. The factors, making considerable impact in enthalpies of dissolution of the studied compounds in water, are revealed.
\end{abstract}

Keywords: Tetrapyridylporphyrin, dissolution enthalpies, interparticle interaction.

\section{Introduction}

Wide variety and complexity of porphyrins structure define specificity of their behaviour in chemical reactions and physical-chemical processes, which take place in solutions. Application of calorimetric method to solvation studies of the porphyrin molecules represents an essential practical and theoretical interest as it allows to characterize directly energetics of interparticle interaction in a solution.

The majority of research work on porphyrins and their complexes are carried out in nonaqueous media. The same is true for thermochemical measurements. In spite of the available commercial production of the precision calorimetric measurement techniques, the chemists outside Russia almost did not deal with problem of porphyrin solvation in solutions. At the same time there are many works on thermochemistry of dissolution and solvation of natural and synthetic porphyrins in nonaqueous solutions carried out mainly in the Institute of Solution Chemistry of Russian Academy of Sciences and Ivanovo State University of Chemistry and Technology. ${ }^{[1-4]}$

The porphyrins studied here are the halide salts with multiply-charged cations with complex aromatic structure. In these multiply charged cations based on the porphyrin macrocycle and four aromatic pyridine molecules, the positive charge is delocalized along the axes of coordinates $(x$ and $y$ ) of a large solvophobic aromatic matrix. Therefore in aqueous solutions, the ionic solvation of polar organic fragments $\equiv \mathrm{N}^{+} \ldots \mathrm{Hal}^{-}$is combined with the hydrophobic solvation of the porphyrin frame. It is assumed that the reaction centre $\left(\mathrm{H}_{2} \mathrm{~N}_{4}\right)$ of pyridyl porphyrins owing to the macrocyclic effect will weakly participate in solvation. In the case of metallocomplexes the solvation of coordination center $\mathrm{MN}_{4}$ owing to extracoordination $\left(\mathrm{H}_{2} \mathrm{O}\right)_{2} \mathrm{MN}_{4}$ is possible. It is necessary to notice, that both these components of total hydration of the investigated macrocyclic molecules are not described in the literature. ${ }^{[4-7]}$
Our task is to study the influence of cation fragments of tetrapyridylporhyrins, functional substitution and isomerism on the dissolution enthalpies of these compounds. For this purpose the corresponding compounds were synthesized. The derivatives of tetrapyridylporphyrin (I-X) soluble in water were synthesized and purified using procedures described earlier. ${ }^{[8,9]}$

\section{Experimental}

Investigated compounds were dried at $80^{\circ} \mathrm{C}$ in vacuum until constant weight, and placed into calorimetric ampoules before experiment. The heat of dissolution was measured using an isoperibolic calorimeter with automatic collection and processing of results according to the known technique. ${ }^{[8]}$ The invariance of samples after experiment was controlled by UV-vis spectra recorded on Specord M40 and Hitachi U2000 spectrophotometers. Linear dependence of absorption on the concentration of porphyrins in the working range indicates the absence of association in a solution.

\section{Results and Discussion}

Influence of functional substitution on the dissolution enthalpy of 5,10,15,20-tetra(4'-pyridiniumyl)porphyrins

Objects of investigation are derivatives of 5,10,15,20tetra(4',3'-pyridiniumyl)porphyrin presented in Table 1, which are quaternized on pyridyl nitrogen with nonpolar methyl, ethyl and propyl groups (compounds I-III), polar carboxymethyl (IV, V) and carboxyethyl (VI) and lowpolar carboethoxymethyl (VII) groups. The energetics of interpartial interactions (I-VII) in aqueous solution is studied by calorimetric method as the most precise for determination of the changes in dissolution enthalpy of coumpounds I-VII.

Parameters of the uV-vis spectra for unsubstituted tetra(4- $N$-pyridiniumyl)porphyrin in chloroform and compounds I-VII in water are presented in Table 2. These 


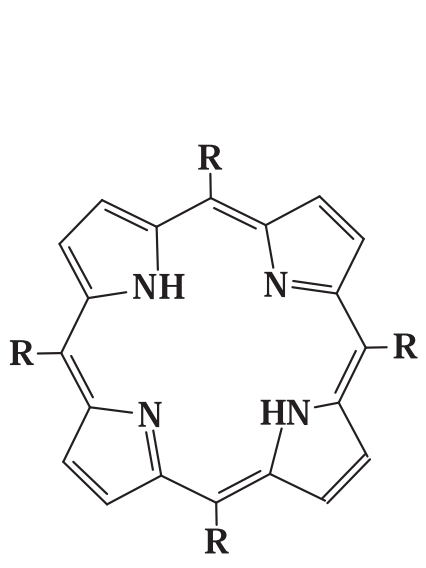<smiles>[AlH2]</smiles><smiles></smiles>

VI<smiles>[R]c1cc[n+](CCBr)cc1</smiles>

VII<smiles>[R]OC(=O)C[n+]1ccc([Cl+])cc1</smiles>

III<smiles>[R]c1cc[n+]([CH2-])cc1</smiles><smiles>[R]c1cc[n+]([CH2-])cc1</smiles>

VIII<smiles>[R]c1ccc[n+](C)c1</smiles>

IX<smiles>[R]c1ccc[n+](CCl)c1</smiles>

$\mathbf{X}$<smiles>[R]c1cccc[n+]1C</smiles>

Table 1. Change of dissolution enthalpies of $4 N$-substituted $5,10,15,20$-tetra(4'-pyridiniumyl)porphyrin in water at $298.15 \mathrm{~K}$.

\begin{tabular}{cc}
\hline Formula, & $\Delta_{\text {sol. }} H^{0}, \mathrm{~kJ} \cdot \mathrm{mol}^{-1}$ \\
$\mathrm{M}, \mathrm{g} \cdot \mathrm{mol}^{-1}$ & $\Delta_{\text {sol }} H^{\mathrm{m}}, \mathrm{J} \cdot \mathrm{mol}^{-1}$ \\
\hline $\mathrm{C}_{44} \mathrm{H}_{38} \mathrm{~N}_{8} \mathrm{I}_{4}$ & $\Delta_{\text {sol. }} H^{0}=116.5 \pm 0.6$ \\
(I) & $\Delta_{\text {sol. }} H^{\mathrm{m}}=116470.3+\left(1.57 \cdot 10^{7}\right) \cdot \mathrm{C}_{\mathrm{m}} \mathrm{H}_{2} \mathrm{P}$ \\
1186.46 & \\
$\mathrm{C}_{48} \mathrm{H}_{46} \mathrm{~N}_{8} \mathrm{I}_{4}$ & $\Delta_{\text {sol }} H^{0}=88.6 \pm 1.9$ \\
(II) & $\Delta_{\text {sol. }} H^{\mathrm{m}}=88647.6+\left(2.38 \cdot 10^{7}\right) \cdot \mathrm{C}_{\mathrm{m}} \mathrm{H}_{2} \mathrm{P}$ \\
1242.57 & \\
$\mathrm{C}_{52} \mathrm{H}_{54} \mathrm{~N}_{8} \mathrm{I}_{4}$ & $\Delta_{\text {sol }} H \approx 82.0$ \\
(III) & dissolved slowly \\
1298.68 & $\Delta_{\text {sol }} H^{0}=74.0 \pm 1.7$ \\
$\mathrm{C}_{48} \mathrm{H}_{38} \mathrm{~N}_{8} \mathrm{O}_{8} \mathrm{Cl}_{4}$ & $\Delta_{\text {sol. }} H^{\mathrm{m}}=73967.1+$ \\
(IV) & $\left(1.12 \cdot 10^{7}\right) \cdot \mathrm{C}_{\mathrm{m}} \mathrm{H}_{2} \mathrm{P}$ \\
996.70 & $\Delta_{\text {sol }} H^{0}=96.5 \pm 4.9$ \\
$\mathrm{C}_{48} \mathrm{H}_{38} \mathrm{~N}_{8} \mathrm{O}_{8} \mathrm{Br}_{4}$ & $\Delta_{\text {sol. }} H^{\mathrm{m}}=96523.4+$ \\
$(\mathbf{V})$ & $\left(2.56 \cdot 10^{7}\right) \cdot \mathrm{C}_{\mathrm{m}} \mathrm{H}_{2} \mathrm{P}$ \\
1174.50 & $\Delta_{\text {sol. }} H^{0}=112.3 \pm 0.6$ \\
$\mathrm{C}_{52} \mathrm{H}_{46} \mathrm{~N}_{8} \mathrm{O}_{8} \mathrm{Br}_{4}$ & $\Delta_{\text {sol. }} H^{\mathrm{m}}=112293.3+$ \\
(VI) & $\left(1.63 \cdot 10^{7}\right) \cdot \mathrm{C}_{\mathrm{m}} \mathrm{H}_{2} \mathrm{P}$ \\
1230.61 & $\Delta_{\text {sol. }} H^{0}=21.7 \pm 0.9$ \\
$\mathrm{C}_{56} \mathrm{H}_{54} \mathrm{~N}_{8} \mathrm{O}_{8} \mathrm{Cl}_{4}$ & $\Delta_{\text {sol. }} H^{\mathrm{m}}=21666.8+$ \\
(VII) & $\left(7.31 \cdot 10^{6}\right) \cdot \mathrm{C}_{\mathrm{m}} \mathrm{H}_{2} \mathrm{P}$ \\
1108.91 &
\end{tabular}

data indicate that polarization of porphyrin molecules in aqueous solutions due to its functional substitution leads to weak hypsochromic shift of the first band and bathochromic shift of the Soret band as compared with a spectrum of unsubstituted tetrapyridylporphyrin in chloroform (Table 2). Slight dependence of UV-vis spectra on the functional substituent indicates weak $\pi$-electronic influence of pyridyl fragments on the porphyrin macrocycle due to the considerable angle between the pyridyl fragment and macrocyclic plane.

Concentration dependence of the enthalpy of dissolution for derivatives of tetrapyridylporphyrin in water $\Delta_{\text {sol }} H^{\mathrm{m}}=f(m)$ in the studied range of concentrations is absent (Figure 1), unlike solutions of the porphyrins in organic solvents. [4] Porphyrin ligand is strong electrolite with dissociation ability, which is determined only by electrostatic interaction of four halide ions and large porphyrin cation.

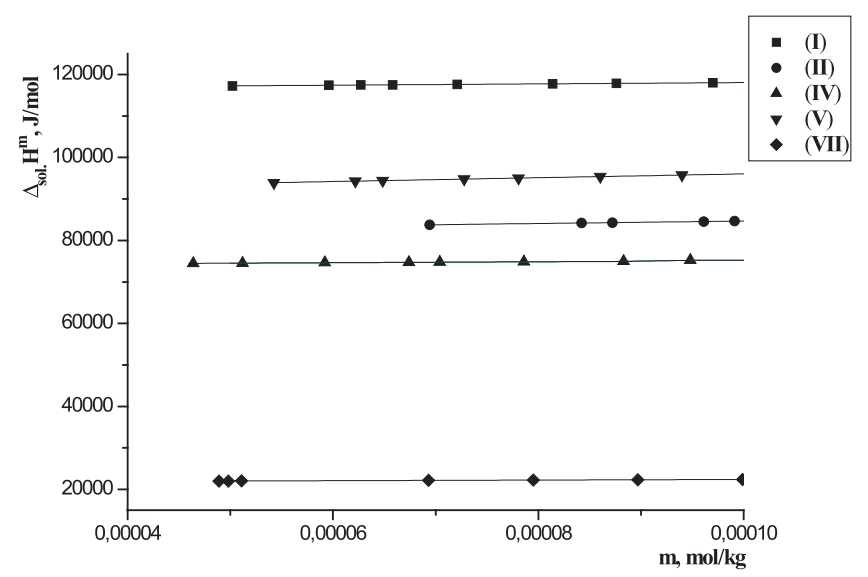

Figure 1. Dependence of dissolution enthalpy $\Delta_{\text {sol. }} H^{\mathrm{m}}$ on the porphyrin molar concentration $m$ (I-VII).

Table 2. The parameters of UV-vis spectra of tetrapyridylporphyrins I-VII.

\begin{tabular}{ccccccc}
\hline Compound & Solvent & $\lambda_{1} /(\lg \varepsilon)$ & $\lambda_{2} /(\lg \varepsilon)$ & $\lambda_{3} /(\lg \varepsilon)$ & $\lambda_{4} /(\lg \varepsilon)$ & $\lambda_{\text {Soret }} /(\lg \varepsilon)$ \\
\hline TPyP & $\mathrm{CHCl}_{3}$ & $643 / 3.29$ & $589 / 3.78$ & $546 / 3.80$ & $514 / 4.13$ & $417 / 5.23$ \\
I & $\mathrm{H}_{2} \mathrm{O}$ & $641 / 3.33$ & $585 / 3.92$ & $554 / 3.86$ & $518 / 4.28$ & $421 / 5.41$ \\
II & $\mathrm{H}_{2} \mathrm{O}$ & $641 / 3.62$ & $585 / 3.94$ & $554 / 3.91$ & $518 / 4.23$ & $422 / 5.40$ \\
III & $\mathrm{H}_{2} \mathrm{O}$ & $641 / 3.62$ & $585 / 3.92$ & $555 / 3.89$ & $519 / 4.19$ & $423 / 5.34$ \\
IV & $\mathrm{H}_{2} \mathrm{O}$ & $641 / 3.65$ & $585 / 4.09$ & $554 / 4.04$ & $518 / 4.42$ & $422 / 5.59$ \\
V & $\mathrm{H}_{2} \mathrm{O}$ & $641 / 3.51$ & $585 / 3.93$ & $554 / 3.88$ & $518 / 4.25$ & $422 / 5.44$ \\
VI & $\mathrm{H}_{2} \mathrm{O}$ & $640 / 3.55$ & $584 / 3.85$ & $555 / 3.83$ & $518 / 4.12$ & $422 / 5.22$ \\
VII & $\mathrm{H}_{2} \mathrm{O}$ & $642 / 3.57$ & $585 / 3.88$ & $553 / 3.786$ & $519 / 4.15$ & $423 / 5.19$ \\
\hline
\end{tabular}


The equations of linear dependence of experimental $\Delta_{\text {sol. }} H^{\mathrm{m}}$ values on molality of solution in the concentration range $(4 \div 10) \cdot 10^{-5} \mathrm{~mol} \cdot \mathrm{kg}^{-1}$ are represented in Table 1 . The standard $\Delta_{\text {sol. }} H^{0}$ values were calculated by extrapolation of the data on $\Delta_{\text {sol. }} H^{\mathrm{m}}$ obtained from 10-15 measurements on zero concentration of porphyrin (Table 1).

The compounds studied differ by the nature and length of functional groups, and the nature of anion, as a result their enthalpy of dissolution varies from 22 to 116 $\mathrm{kJ} \cdot \mathrm{mol}^{-1}$. Generally, $\Delta_{\text {sol }} H$ contains two contributions, those of the phase transition (crystal lattice $\Delta_{\text {cr. }} H$ ) and of solvation (hydrations) $\Delta_{\text {solv. }} H$. Thus, change of the structure of functional substituents in porphyrins will influence both on the stability of the crystal lattice and solvation interactions in a solution:

$$
\Delta_{\text {sol. }} H=\Delta_{\text {cr. }} H+\Delta_{\text {solv. }} H+\Delta_{\text {conf. }} H
$$

where $\Delta_{\text {conf. }} H$ is a change of enthalpy of conformational transitions caused by steric strain of molecular fragments in transition from a crystal in a solution (as the contribution in solvation represents «...the sum of energetical and structural changes connected with transition of atomic and molecular particles from a gas phase to the solvent .... ${ }^{[10, p .36]}$ ).

It follows from the Table 1, that the enthalpies of dissolution of porphyrins in water are endothermic. Perhaps it is caused by the large energy expenses for the distruction of water structure by introduction in the solution of large molecules of porphyrins. Dissolution of compound I, which has no functional substituents tending for hydration is the most endothermic. Iodide is most poorly hydrated comparing with chlorides and bromides. ${ }^{[1]}$ Presumably these compounds have the strongest crystal lattice, because their molecules are most compact, in comparison with the others.

Replacement of methyl groups at pyridyl nitrogen by ethyl also does not promote interaction with water, but, apparently, changes packing of the molecules in II, reducing the energy of crystal lattice. As a result, the endoeffect of dissolution for II is by $27.9 \mathrm{~kJ} \cdot \mathrm{mol}^{-1}$ lower in comparison to I. Further lengthening of $\mathrm{N}$-alkyl substituent in the pyridyl fragment of porphyrin III decreases its solubility in water due to the increase of a hydrophobic properties of the molecule. Therefore only evaluated value is presented for $\Delta_{\text {sol }} H$ in Table 1.

Substitution of four $N$-pyridyl positions for carboxymethyl (IV, V) or carbethoxymethyl (VII) groups leads not only to disordering of a crystal lattice in comparison with $\mathbf{I}$, but also to strengthening of solvation due to formation of hydrogen bonds with water molecules like - $\mathrm{COOH} \cdots \mathrm{H}_{2} \mathrm{O}$ and $-\mathrm{C}\left(\mathrm{OC}_{2} \mathrm{H}_{5}\right) \mathrm{O} \cdots \mathrm{H}_{2} \mathrm{O}$. The total effect of these contributions is within $43-95 \mathrm{~kJ} \cdot \mathrm{mol}^{-1}$, depending on the molecule structure. For tetra(1-carboxymethyl-4pyridiniumyl)porphine tetrachloride (IV) the energy gain is $42.5 \mathrm{~kJ} \cdot \mathrm{mol}^{-1}$, for tetra(1-carboxymethyl-4-pyridiniumyl) porphine tetrabromide $(\mathbf{V})-20 \mathrm{~kJ} \cdot \mathrm{mol}^{-1}$. The difference in $22.5 \mathrm{~kJ} \cdot \mathrm{mol}^{-1}$ is caused by the nature of stabilizing anion $\left(\mathrm{Cl}^{-}\right.$or $\left.\mathrm{Br}\right)$. It is known, ${ }^{[11]}$ that the difference in $\Delta H$ value for $\mathrm{Cl}^{-}$and $\mathrm{Br}$ for hydrations of these ions is $33.5 \mathrm{~kJ} \cdot \mathrm{mol}^{-1}$. From comparison of these literature and our experimental data it follows that essential leveling influence is large hydrophobic of porphyrin cation on four halide anion is observed.
Addition of propionic substituents to $N$-pyridyl fragments of porphyrin molecules (VI), evidently, contributes additionally to decay of the water structure which is not compensated by hydration of carboxy groups. As a result endothermicity of dissolution of VI in water increases almost by $15.8 \mathrm{~kJ} \cdot \mathrm{mol}^{-1}$ in comparison with $\mathbf{V}$ and reaches 112.3 $\mathrm{kJ} \cdot \mathrm{mol}^{-1}$.

For compound VII the value of enthalpy of dissolution is less endothermic $\left(21.7 \mathrm{~kJ} \cdot \mathrm{mol}^{-1}\right)$, i.e. replacement of carboxymethyl groups by carbethoxymethyl ones leads to the energetic gain of dissolution process by $52.3 \mathrm{~kJ} \cdot \mathrm{mol}^{-1}$ as compared to IV. Possibly, it is caused by additional action of four ethyl groups on a crystal lattice of porphyrin molecule.

\section{Influence of tetrapyridylporphyrin isomerism on the enthalpies of dissolution in water}

In the case of porphyrins the $\pi$ - $\pi$-interactions have the significant contribution to the energy of intermolecular intareactions in a crystal lattice. ${ }^{[12]}$ It is obvious, that for a such type of interactions interplane distances between molecules in crystal should be close to minimum. The deviation of porphyrin molecule from planarity due to functional substitution or other reasons decreases intermolecular $\pi-\pi$ interactions and energy of the crystal lattice. The latter should decrease the endothermicity of dissolution enthalpy of porphyrins. Such a dependence was earlier observed experimentally for derivatives of tetraphenylporphyrin. ${ }^{[13]}$

Authors ${ }^{[14]}$ have studied the dependence of free volume $\left(V_{\text {free }}\right)$ of tetraphenylporphyrin molecules as a function of a size and arrangement of the substituent in phenyl rings. It was established, that these values remain nearly constant for porphyrins with substituents located in para-position and increase for $m e t a$ - isomer and ortho-derivatives. It is possible to assume, that among $N$-methylated derivatives of tetra(4-, 3- and 2-pyridyl)porphyrins the molecular volume changes similarly. The latter should lead to the weakening of a crystal lattice of compounds in this series. The experimental data confirm this suggestion. So, the standard dissolution enthalpy of porphyrins, differing only by the position of $\mathrm{N}$-atom in pyridyl fragments, respectively decreases in the order $116.5>78.6>48.3 \mathrm{~kJ} \cdot \mathrm{mol}^{-1}$ (Table 3).

Table 3. Change of solution enthalpies for $N$-derivatives of tetra(3-,2-pyridyl)porphyrin in water at $298.15 \mathrm{~K}$.

\begin{tabular}{cc}
\hline $\begin{array}{c}\text { Formula, } \\
\mathrm{M}, \mathrm{g} \cdot \mathrm{mol}^{-1}\end{array}$ & $\begin{array}{c}\Delta_{\text {sol. }} H^{0}, \mathrm{~kJ} \cdot \mathrm{mol}^{-1} \\
\Delta_{\text {sol. }} H^{\mathrm{m}}, \mathrm{J} \cdot \mathrm{mol}^{-1}\end{array}$ \\
\hline $\mathrm{C}_{44} \mathrm{H}_{38} \mathrm{~N}_{8} \mathrm{I}_{4}$ & $\Delta_{\text {sol. }} H^{0}=116.5 \pm 0.6$ \\
$(\mathbf{I})$ & $\Delta_{\text {sol. }} H^{\mathrm{m}}=116470+\left(1.57 \cdot 10^{7}\right) \cdot \mathrm{C}_{\mathrm{m}} \mathrm{H}_{2} \mathrm{P}$ \\
1186.46 & $\Delta_{\text {sol. }} H^{0}=78.6 \pm 3.9$ \\
$\mathrm{C}_{44} \mathrm{H}_{38} \mathrm{~N}_{8} \mathrm{I}_{4}$ & $\Delta_{\text {sol. }} H^{\mathrm{m}}=78600+\left(7.09 \cdot 10^{7}\right) \cdot \mathrm{C}_{\mathrm{m}} \mathrm{H}_{2} \mathrm{P}$ \\
$(\mathbf{V I I I I})$ & \\
1186.46 & $\Delta_{\text {sol. }} H^{0}=15.1 \pm 0.6$ \\
$\mathrm{C}_{56} \mathrm{H}_{54} \mathrm{~N}_{8} \mathrm{O}_{8} \mathrm{Cl}_{4}$ & $\mathrm{Sl}^{\mathrm{m}}=15100+\left(2.11 \cdot 10^{7}\right) \cdot \mathrm{C}_{\mathrm{m}} \mathrm{H}_{2} \mathrm{P}$ \\
$(\mathbf{I X})$ & \\
1108.91 & $\Delta_{\text {sol. }} H^{0}=48.3 \pm 2.7$ \\
$\mathrm{C}_{44} \mathrm{H}_{38} \mathrm{~N}_{8} \mathrm{I}_{4}$ & $(\mathbf{X})$ \\
1186.46 & $\Delta_{\text {sol. }} H^{\mathrm{m}}=48310+\left(2.21 \cdot 10^{7}\right) \cdot \mathrm{C}_{\mathrm{m}} \mathrm{H}_{2} \mathrm{P}$ \\
\hline
\end{tabular}


The greatest contribution to a crystal lattice loosening of porphyrins is brought by carbethoxymethyl substituent at nitrogen atom in meta-position of pyridyl ring (IX). This leads to the least endothemic value of dissolution enthalpies.

Thus, from the comparative analysis of the obtained data it follows:

- the synthesized quaternized derivatives of tetrapyridylporphyrin series are dissolved in water with high endoeffect, in comparison with the similar molecules in organic solvents; it is caused by properties of water as a solvent; ${ }^{[5,15-17]}$

- enthalpies of dissolution of $N$-carboxymethyl substituted tetrapyridylporphyrins in water essentially depend on the nature of anion $\left(\mathrm{Cl}^{-}\right.$or $\left.\mathrm{Br}\right)$;

- change of position of heteroatom in pyridyl fragment of porphyrin (para-, meta-, ortho-positions) has significant effect on enthalpies of dissolution in water, due to the energy change of the crystal lattice, that decreases in the transition from para- to meta- to ortho-isomers.

Acknowledgements. Authors thank Russian Foundation for Basic Research (grant № 10-03-00020a).

\section{References}

1. Dostizheniya i Problemy Teorii Solvatatsii [Achievements and Problems of the Solvation Theory] (Kutepov A.M., Ed.). Moskva: Nauka, 2001. (in Russ.)

2. Problemy Khimii Rastvorov i Tekhnologii Zhidkofaznykh Materialov. [The Problems of Solution Chemistry and Technology of Liquid-Phase Materials]. Ivanovo: ISC RAS, 2001. p. 312 (in Russ.)

3. Problemy Khimii Rastvorov i Tekhnologii Zhidkofaznykh Materialov. [The Problems of Solution Chemistry and Technology of Liquid-Phase Materials]. Ivanovo: ISC RAS, 2006. p. 322 (in Russ.)

4. Berezin M.B. Termokhimia Solvatatsii Khlorofilla i Rodstvennykh Soedineny [Thermochemistry of Solvation of Chlorophyll and Related Compounds]. Moskva: Krasand, 2008. 256 p. (in Russ.)
5. Mishchenko K.P., Poltoratsky G.M. Termodinamika i Struktura Vodnykh i Nevodnykh Rastvorov Elektrolitov [Thermodynamics and Structure of Aqueous and Nonaqueous Solutions]. Leningrad: Khimia, 1976. 328 p. (in Russ.)

6. Berezin B.D. Koordinatsionnye Soedineniya Porfirinov $i$ Ftalotsianina [Coordination Compounds of Porphyrins and Phthalocyanine]. Moskva: Nauka, 1978. 280 p. (in Russ.)

7. Berezin D.B. Makrotsiklichesky Effect i Strukturnaya Khimia Porfirinov [Macrocyclic Effect and Structure Chemistry of Porphyrins]. Moskva: Krasand, 2010. 424 p. (in Russ.)

8. Berezin M.B, Berezina N.M., Semeikin A.S., Vjugin A.I. Zh. Obshch. Khim. 2007, 77, 1905-1908 (in Russ.).

9. Berezin M.B., Berezina N.M., Bazanov M.I., Semeikin A.S., Vjugin A.I. Russ. J. Coord. Chem. 2010, 36, 631-636.

10. Krestov G.A., Berezin B.D. Osnovnye Ponyatiya Sovremennoy Khimii [Basic Concepts of Modern Chemistry]. Leningrad: Khimia, 1986. 104 p. (in Russ.).

11. Yatsymyrsky K.B. Termokhimia Kompleksnykh Soedineny [Thermochemistry of Complex Compounds]. Moskva: Izdatelstvo AN SSSR, 1951. p. 51. (in Russ.)

12. Vjugin A.I., Antina E.V., Berezin M.B. Termodinamika Molekulyarnogo Kompleksoobrazovaniya v Rastvorakh Pripodnykh Porfirinov [Thermodynamics of Molecular Complexformation in Solutions of Natural Porphyrins]. In: Biologically Active Compound in Solutions. Structure, Thermodynamics, Reactivity. (Kutepov A.M., Ed.). Moskva: Nauka, 2001. p. 298-325. (in Russ.)

13. Balantseva E.V., Antina E.V., Berezin M.B, Vjugin A.I. Russ. J. Phys. Chem. A 2004, 78, 1633-1637.

14. Zielenkiewicz W., Perlovich G.L., Nikitina G.E., Semeykin A.S. J. Solution Chem. 1996, 25(2), 135.

15. Krestov G.A., Vinogradov V. I., Kessler J.M., etc. (Авторам! указать всех соавторов) Sovremennye Problem Khimii Rastvorov [The Modern Problems of Solution Chemistry]. Moskva: Nauka, 1986, 264 p. (in Russ.).

16. Krestov G.A. Termodinamika Ionnykh Protsessov v Rastvorakh [Termodinamics of Ionic Processes in Solutions]. Leningrad: Khimia, 1973. 304 p. (in Russ.)

17. Berezina N.M., Bazanov M.I., Berezin M. B, Semeikin A.S. Izv. Vyssh. Uchebn. Zaved., Khim. Khim. Tekhnol. 2008, 51(11), 61-69 (in Russ.). 